\title{
The Effectiveness of Blended Learning Model to Promote Physics Students' Critical Thinking Skill
}

\section{Bahtiar $^{1 *}$}

${ }^{1}$ Tadris Physics Study Program, Universitas Islam Negeri Mataram, Indonesia

\author{
*e-mail: bahtiar79@uinmataram.ac.id
}

\begin{abstract}
Critical thinking skills that are claimed to be in the medium and low categories require special attention. Efforts that can be made to overcome these problems are to use an explicit learning model to develop students' critical thinking skills by considering the integration of technology in the learning process. This study aimed to describe the validity, practicality, and effectiveness of blended learning model in promoting critical thinking skill. This study garnered the data regarding the validity from three validators. The practicality of the learning model was based on the applicability of the learning model, students' responses and challenges faced throughout the teaching and learning process; while the effectiveness of the learning model was based on the increase of the critical thinking skill. The empirical evidence showed that the average score given by the three validators was 3.7 with the percentage of $90 \%$ reliability, which falls into a very valid category. The blended learning model enabled the students to develop their critical thinking skill with the average achievement 0.83 for each indicator of critical thinking. This study concluded that the blended learning model was valid, practical, and effective to promote students' critical thinking skill. The results of this study can be used as an alternative solution to improving students' critical thinking skills that are relevant to technological developments.
\end{abstract}

Keywords: Blended Learning, Validity, Practicality, Effectiveness, Critical Thinking

\section{Introduction}

The critical thinking skill is an activity or cognitive process to gain knowledge, understanding, and skills for the sake of alternative and making deductive, inductive, and evaluative decisions through a deep thinking process regarding the things achieved by one's experiences, evaluation and logical thinking that can be measured through the interpreting, analyzing, introductory assumptions, deductions, evaluative reference, explanation, and selfregulation skill (Fitriani et al., 2019). Critical thinking enables students to search for truth resulting from phenomenon and from any information. Critical thinking skill needs to be developed as it allows the students to easily understand concept and to be sensitive toward problems and its solution, and enables them to apply the conceptual knowledge in any circumstances (Sanders et al., 2011). Through critical thinking, the students are encouraged to think actively and effectively to develop self-knowledge (Suhirman et al., 2021), lead to better working performance and thoughts (Deperlioglu \& Kose, 2013). Critical thinking skills also enables the students to associate certain problems more accurately (Kasalei et al., 2020).

The critical thinking skills aim to overcome problems, so that the problems are revealed and associated to one another. These thinking skills include understanding, comprehending, analyzing and even recalling information previously taught by the lecturer. Critical learning refers to ways to guide students to develop critical thinking skills. The use of critical thinking in learning fits the scientific approach where the students are demanded to create hypothesis and conclusion from any process of observation of certain phenomena from which a scientific theory of the world is developed (Fisher, 2011). Critical thinking features the following basic competences, such as the ability to recognize and analyze problems, figure out solutions, collect and organize relevant information (Ennis, 1993).

\footnotetext{
${ }^{*}$ Corresponding author.
} 
Critical thinking skill can be divided into five bigger elements, namely: (1) focusing on problems, (2) analyzing opinions and appropriateness in explaining questions, (3) determining the strength for taking conclusion from facts and factual information in the field, (4) determining logical flow and conclusion already made, and (5) making sure that the efforts or objectives already made are believable (Gelder, 2005).

One of the purposes of education is to produce highly critical learners in terms of problem solving and expressing their ideas in critical way (Baker, 1997). Critical thinking claimed as an important skills that must be achieved by student in learning (Davies \& Barnett, 2015; Guo \& Wang, 2021; Larsson, 2017; Rombout et al., 2021). In fact, most pedagogical practices did not promote students' critical thinking skills. Not surprisingly, this happened because there was debates on what critical thinking really is (Bensley \& Murtagh, 2012; Moore, 2013; Verawati et al., 2020). Furthermore, described that, two factors contributing to this drawback are the curriculum that does not focus on the development of the specific skills. It too comprises general scope in that the lecturer is forced to finish the materials (Baser et al., 2016). Also, the lack of the lecturer's knowledge about the learning method that contributes to critical thinking skill develop is also the contributing factor (Phillips, 2007; Verawati et al., 2020). Openness is needed from all respective stakeholders to enhance educational purpose (Setyowati et al., 2011), in this context is critical thinking skills.

Context in Indonesia, students' critical thinking skills are still in the medium (Bahtiar et al., 2018) and low category (Suhirman et al., 2020) so it needs to be developed (Fitriani et al., 2019). This is because teachers and lecturers do not know how to teach students critical thinking skills (Prayogi et al., 2018). This skill can be developed by promoting the students' intellectual (Yuliati et al., 2012). The use or development of an explicit learning model to develop critical thinking skills needs to be done (Asy'ari, Ikhsan, et al., 2019). The blended learning model can be used as an alternative solution to the problems described and relevant to the current situation, which demands that learning adapt to technological changes (Siron et al., 2020). Blended learning as a learning approach that integrates FTF and distant learning using a learning management system and various communication tools employed by students and lecturers (Harding et al., 2012). Blended learning does not totally replace the FTF learning, yet it compliments and missing materials in the FTF classrooms. Lecturers use computer technologies with the internet access to provide information, learning materials and readings. Some lecturers allow students interactive communication with the use of asynchronous and synchronous technologies. Asynchronous communication is defined as instruction or communication that occurs in different time and location spectrum, while synchronous communication is regarded as instruction or communication that simultaneously happens in real time, anywhere and anytime and in various locations (Fenton \& Watkins, 2014).

Blended learning can be defined as a learning process that integrates various approaches where different technologies and media are used. Suffice it to say that blended learning is a learning approach that combines FTF using a computer media (offline), and computer online (internet and mobile learning). The materials delivered through the media include graphs, texts, animations, simulations, audio, and video (Effendi \& Hendriyani, 2020) (Prayitno, 2015). Blended learning is the integration of FTF and online learning that draw on the use of the internet to supplement learning. Basically, the students participate in any form of communication and environment. According to research and experts, online learning forum can encourage introvert students to communicate directly to the lecturer and discussion (Birch \& Volkov, 2007). Online discussion also solves their communication barriers and encourages them to express their ideas. The marriage between online and FTF provides an effective learning experience for both the lecturer and students. What is more, this learning model also enables students to think and evaluate their work collaboratively while giving suggestion for revisions. Another research suggests that online peer-feedback as the alternative to FTF communication can motive students to learn, participate and collaborate (Yongxing, 2008). The characteristics of blended learning are very relevant to creating effective learning that emphasizes on (1) involving learning in the process of learning; (2) encouraging creativity for independent learning (learning how to learn); (3) 
improving knowledge and learning skills; (4) motivating for further learning (Arends, 2012), so that learning essential skills such as critical thinking can be realized.

Good lectures are the ones that are adhered to the curriculum in which it requires 50 minutes per/credit of topic course, yet it was mainly hampered by the inconvenience of the classrooms. Consequently, the class meeting was less effective. For this reason, a novel learning strategy is needed to maximize the lectures. Such an effective learning strategy can be blended learning model, a marriage between face to face (FTF) and e-learning. The use of blended learning at UIN Mataram plays a complimentary role in that it can facilitate learning beyond the classrooms that compliments the less effective FTF instruction. Through e learning, students can optimize their time to learn as they can access the materials easily (Deperlioglu \& Kose, 2013). The strength of blended learning is the mediation of worthy learning experience for both the lecturer and students. The following are some pedagogical benefits of blended learning: (1) promoting academic prestige, (2) minimizing the number of drop out through online support of the lecturer, (3) providing flexible learning model that can be applied to heterogeneous students, (4) saving expenses and optimizing the learning hours. Given the educational advantages, it is incumbent upon the tertiary education or universities to employ the blended learning model (Staker \& Horn, 2012). Previous studies unveiled that $50 \%$ of learning outcomes could be attained through blended learning model in 2019 (Jones et al., 2006). In addition, blended learning enables students to discuss online. This allows the students, even introvert students to express their ideas (Berge, 2013).

Previous study related to the implication of blended learning showed the significant impact on students' learning outcome (Dewi, 2013). Furthermore, empirical studies showed that the students who learn using blended learning model have higher content mastery compared to those who learn using conventional method. With respect to rationale, the empirical evidence suggested that the students in blended learning classroom outperformed their counterparts in the conventional classrooms. It was found that there was an effect of blended learning model on the content mastery of science students and their scientific thinking (Hermawnato et al., 2013). Another research suggests that the students' prestige and motivation are significantly different from that of the students learning using FTF only (Syarif, 2013). Unfortunately, these studies do not explicitly aimed to promote students' critical thinking skills. In addition, the learning that is implemented does not explicitly describe the steps of the blended learning model used.

The Community of Inquiry (Col) learning model is claimed to be a blended learning model that integrates online features in inquiry learning steps as the basis for learning activities such as (1) presenting problems that aim to arouse student curiosity and define questions keys or issues to carry out investigations; (2) investigating which in practice emphasizes students to exchange opinions and investigate sources of information with other students; (3) integration of the implementation by connecting previous ideas or concepts with the results of the investigation (reflection); (4) resolutions / applications which in the process ask students to apply new ideas or defend proposed solutions (Garrison \& Vaughan, 2012; Graham, 2015). The obstacles that often arise in learning using the blended learning model are difficulties in interacting cognitive, affective, and student behavior components (Dziuban et al., 2018). In addition, online learning problems are related to inadequate internet accessibility, technical skills, administrative support, and insufficient content design (Anggraeni \& Sole, 2018), student motivation to study independently (Chaeruman, 2018; Anas Pratama \& Arief, 2019) which is exacerbated by students' ignorance about online learning (Kaunang \& Usagawa, 2017). The description of the results of this study contradicts the expectation that during the Covid-19 pandemic, online learning is expected to provide the same benefits and motivation as face-to-face learning (Lynch, 2020). These studies that have been described have applied a web-based learning model but have not found a blended learning model that has phases that accommodate science learning activities that emphasize physical and mental activity (Bahtiar et al., 2018) and explicitly teach critical thinking skills, so that the demands of science learning according to these activities have not been fulfilled. In addition, the results of preliminary research conducted at UIN Mataram found that $35 \%$ of students often use Wi-Fi facilities to open social media such as Facebook, 
Twitter and Instagram. Students only use internet facilities when they get assignments from lecturers to write papers to find information, scientific articles, and teaching materials. On the other hand, $85 \%$ of students stated that they had difficulty finding credible and relevant material for the purposes of completing the given assignment. Furthermore, it is known that $75 \%$ of the courses have never used e-learning which has structured steps like the previous offline learning process.

This study aimed to develop a blended learning model based on an inquiry learning model that integrates online features into known inquiry learning steps which are integrated with there are three phases of blended learning model application based ICT, namely: (1) seeking for information, (2) acquisition of information, and (3) synthesizing of knowledge (Ramsay, 2001) to improve critical thinking skills with components (1) formulating problems, (2) formulating hypotheses, (3) designing experiments, (4) conducting experiments, (5) analysis, and (6) conclusions. This research is very important to do, considering the importance of teaching critical thinking skills through structured steps (Bahtiar et al., 2018) and relevant to technological developments (Anggraeni \& Sole, 2018; Siron et al., 2020; Yustina et al., 2020).

\section{Method}

This development research generates blended learning model to develop physics students' critical thinking skills undergirded by 4-D, namely Define, Design, Develop, and Disseminate (Thiagarajan et al., 1974) which includes testing the validity, practicality, and effectiveness of the developed learning model. The first phase of product development testing is model validation which includes two components, namely content validity and construct validity (Nieveen, 1999) by three competent experts using the learning model validation sheet. The data from the validation of the learning model were analyzed descriptively qualitatively by making the average score obtained from the validator. Assessment of the validity of the learning model consists of 4 rating scales, namely, not valid $=1$, less valid $=2$, valid $=3$, and very valid $=4$ (Ratumanan \& Laurens, 2006). Scores obtained from expert assessment are then converted into scale 4 qualitative data, as presented in Table 1.

Table 1. The validity of learning model

\begin{tabular}{cc}
\hline Score & Criteria \\
\hline$>3.6$ & Very valid \\
$3.0-3.6$ & Valid \\
$1.9-2.9$ & Less valid \\
$1.0-1.8$ & Not valid \\
\hline
\end{tabular}

The average value of the validity and reliability of the learning model is determined based on the value given by the validator which is calculated using the percentage agreement equation. The learning model is declared reliable if it has a percentage agreement of $\geq 75 \%$ with valid category (Borich, 2016). Observation data were collected using observation sheets carried out by two observers on aspects such as seeking of information, acquisition of information, and synthesizing of knowledge as a reference to determine the practicality of the learning model that has been developed. Data on the practicality of the learning model in terms of the feasibility of learning which is assessed using a scale score of 4 with category $1=$ not good, $2=$ poor, $3=$ good, and $4=$ very good (Ratumanan \& Laurens, 2006) and interpreted according to Table 2.

Student responses after learning are also identified to determine the practicality of the learning model that has been developed. Student response data were collected using a questionnaire with a Guttman scale. The percentage of student responses is determined using the equation $[P=(\Sigma K / \Sigma N) \times 100 \%]$ with the criteria (1) very weak: $1 \%-20 \%,(2)$ weak: $21 \%-40 \%$, (3) sufficient: $41 \%-60 \%$, (4) strong: $61 \%-80 \%$, and (5) very strong: $81 \%$ 
- 100\% (Riduwan, 2007). This research design used a one-group pretest-posttest design (Fraenkel et al., 2011) involving 50 students at the Tadris Physics Study Program, Universitas Islam Negeri Mataram. Students' critical thinking skills are measured using a critical thinking skills test instrument with indicators: (1) formulating problems, (2) formulating hypotheses, (3) designing experiments, (4) conducting experiments, (5) analysis, and (6) conclusions. Students' critical thinking skills n-gain scores were analyzed using the N-Gain equation and grouped into high (score: $>0.7$ ), moderate (score: $0.3-0.7$ ), and low (score: $<0.3$ ) categories (Hake, 1999).

Table 2. Practicality of the learning model

\begin{tabular}{cc}
\hline Score & Category \\
\hline $1.0-1.8$ & Not good \\
$1.9-2.7$ & Poor \\
$2.8-3.6$ & Good \\
$>3.6$ & Very good \\
\hline
\end{tabular}

\section{Result and Discussion}

\section{Results}

\section{Validity of Blended Learning Model}

The result of validation model by three validators (Figure 1) includes the aspects, such as: (1) theoretical support; (2) syntax; (3) specific purposes of learning model; (4) management system and learning environment. Based on the Figure 1, the validity was found to be highly valid. Generally, all the three validators gave 3.7 and $90 \%$ reliability, which is very valid. More specifically, the validity of the learning model is divided into several sub evaluations, such as the suitability of learning theory with the average evaluation of the validators was 3.6, which means it was very valid and can be used with minor revisions. This was based on the definition that learning model is a conceptual framework that represents systematic procedure for the organization of learning experience for the sake of certain learning outcomes and plays role as a guidelines for lecturers to design their future instruction (Ally, 2004). Syntactic model with average score of 4 was categorized into valid and can be applied without revisions. Drawing on several studies of blended learning, the experts in this study concur with the use of three syntactic models of the learning approach. In addition, specific learning purposes as shown in the Figure 1 above are regarded as very valid with the mean score 3.8. Basically, the primary purposes of learning model is to help develop students individually to figure out their own problems.

\section{Practicality of Blended Learning Model}

The applicability of the learning model was determined from the observation of the supervisor throughout the learning process in the classroom. This can be measured from the applicability of the lesson plan; students' responses regarding the learning, and challenges they faced during the learning. Figure 2 shows that the applicability of the lesson was very good with the total percentage of $86 \%$. This percentage was gained through total of mean score from three raters. The average score of each rater was 3.4 (good) from each criterion. The results showed that the applicability of the learning model was very good. These findings are reinforced by the positive response of students after learning as shown in Figure 3. Figure 3 is the data generated from the questionnaires distributed soon after the application of the learning model. The data represents rating scales from 1 to 5 that collects students' interests in learning. 37 students gave the average of 3.4 with 85.5 percent, which falls into very good category. The statement between 6 and 9 represent the construct of ease of understanding and learning of the materials that show the average score of 3.41 with the average percentage of 85.2 , which refers to very good category. The statements of between 10 and 14 represent the students' responses regarding the engagement and bravery to 
express ideas with the average score of 3.45 and average percentage of 8.61 , which falls into very good category. Similarly, statements from number 15 to number 16 show a very good category with the percentage of 87.4. These two statements represent the construct of ease of the students in concluding the learning activities.

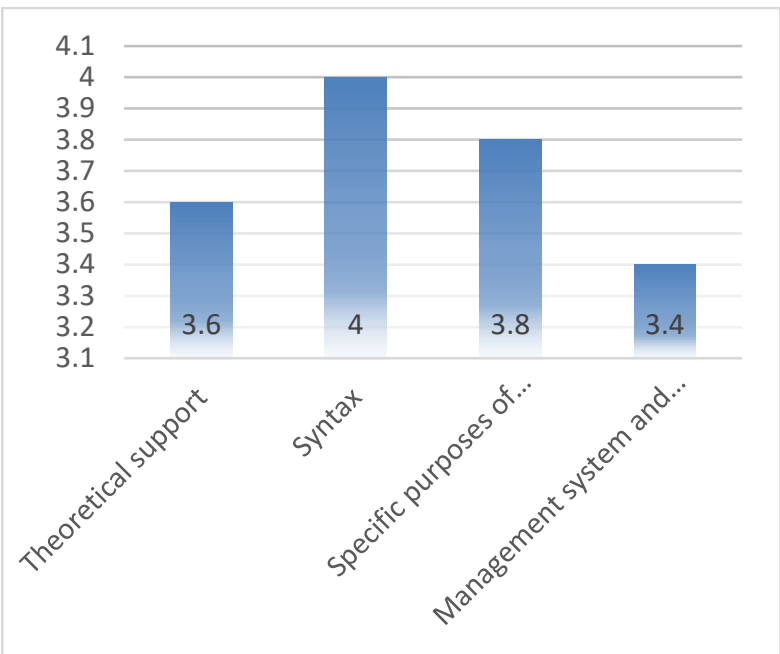

Figure 1. Learning model validity

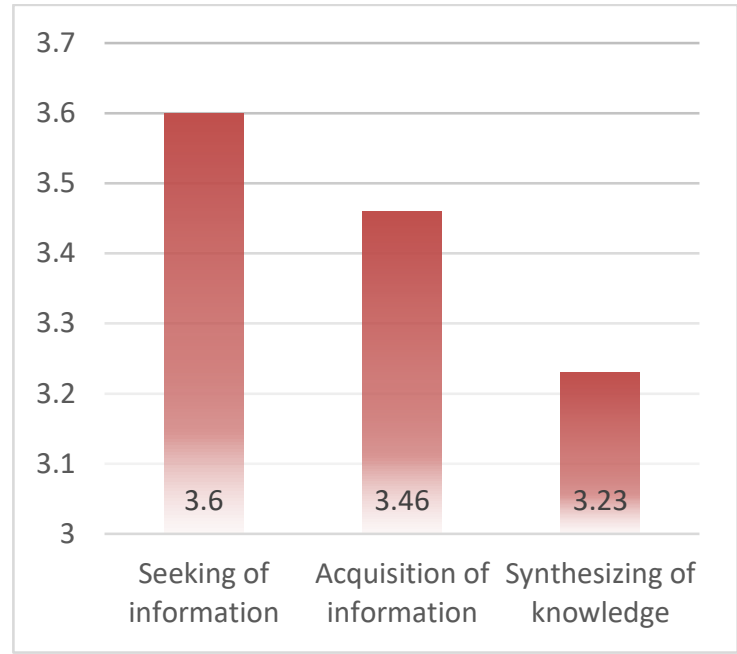

Figure 2. The applicability of the lesson

The challenges found in the field are a series of events such as students learning activities, facilities, time and others that are contrary to the learning design. This study figured out that there were several challenges hampering the quality of the application of the learning process, namely the novelty of the learning system. The students felt that the way they learnt was new. In addition, the questions that require high thinking skills are regarded as new to them that the lecturer needed some time to delineate to the students. As a result, the learning was not based on the lesson plan as the students require further explanation. The students in the last period of their cognitive development known as Piaget, a formal operation phase, should have been able to think of abstract concepts, locals, and interpret complex information. Giving the explanation and guidance of the abovementioned problems beyond the classrooms can be the panacea. Another challenge in the learning process includes the difficulty in integrating learning-based culture and identifying musical instruments of local culture although the lecturer in fact used to give scaffolding for the students on individual or collaborative basis, and used to instruct them to base their learning on the assessment book as their guidance. The students who never performed any experiments tended to be resistant in the classrooms and did not focus on the learning, all of which hampered the learning process. This happens because they forget their own local culture as new immerging things are burgeoning among them. This made the lecturer to repeatedly give advices, reinforcement, and guidance for the students during the teaching and learning process.

\section{Effectiveness of Blended Learning Model}

The process of the blended learning model also contributed to the escalation to the learning outcomes (Trilling \& Fadel, 2009). This was evident from the indicators, such as the increase of students' critical thinking skills as presented in Figure 4. Students' critical thinking skills improve after being taught using a blended learning model that emphasizes inquiry processes with actualization of teaching material with daily life (high category with average score: 0.8$)$. The results of this study indicate that the blended learning model developed is effective for improving critical thinking skills. 


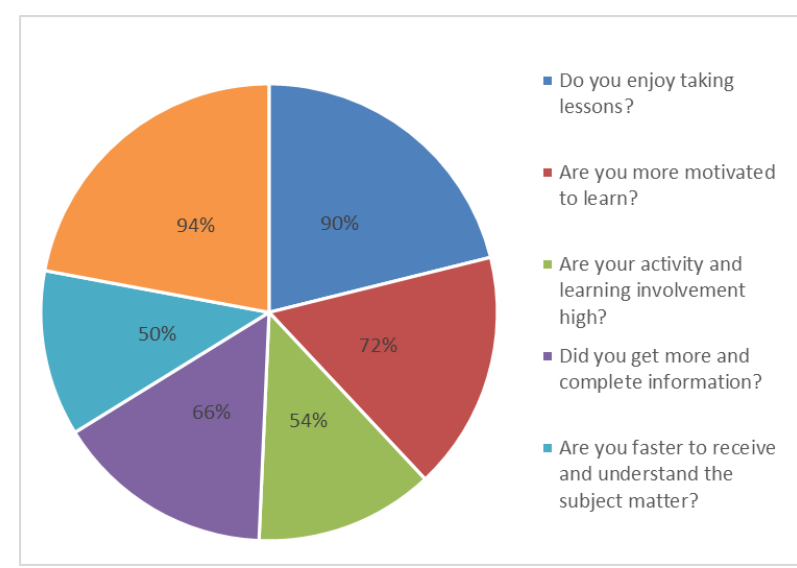

Figure 3. Students' responses

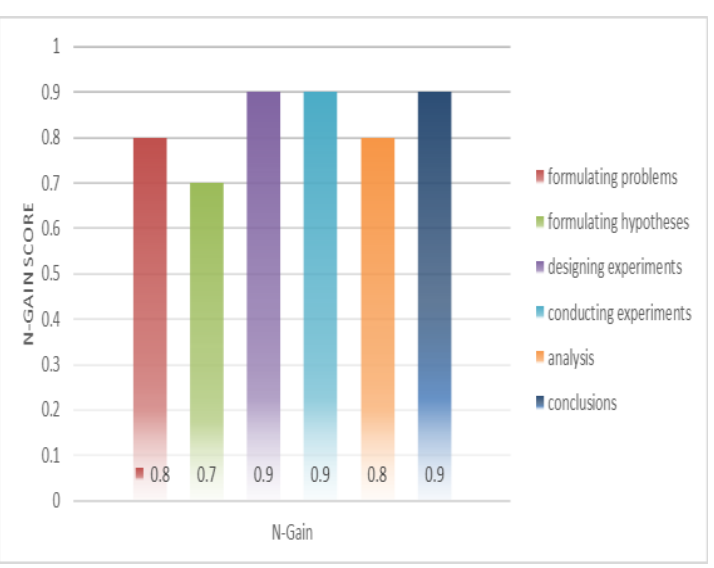

Figure 4. Students' critical thinking skills ngain

\section{Discussion}

Blended learning model validated through Focus Group Discussion (FGD) activities by three competent experts. A valid blended learning model according to relevant the theoretical support (score: 3.6), syntax (score: 4), specific purposes of learning model (score: 3.8), and management system and learning environment (score: 3.4 ) aspects is achieved. In line with these findings, product validation can be performed through FGD activities by experts (Murgado-Armenteros et al., 2012). Previous study developed project based blended learning. Blended learning model developed based on problem-based learning and implemented on computer network design and management course. The study shows that model developed effective to improve students learning activities. The result also show that the model developed fulfill all components of learning model. Unfortunately, the model validity not detailed comprehensively and purposed only to facilitated students' activities and not specifically purposed to improve students' critical thinking (Saputra et al., 2019). Furthermore, another research founded that blended learning model helping student to achieve learning objective, effective learning environment, and communicating ideas and information (Dziuban et al., 2018; Kintu et al., 2017). These results not describe specifically what learning objectives were purposed like this study identified.

The blended learning model developed in this study emphasizes the suitability of learning material with the student's environment (score: 3.4 , valid category) so that it allows students to maintain learning motivation to maximize the achievement of learning objectives. Previous result stated that blended learning model maximized students' oral proficiency and motivation (Wichadee, 2017). In the other hand, another studies found that utilize online media show that mobile learning developed is declared valid for use in learning but is different in reviewing the composing aspects and the purpose of developing the blended learning model of this study such as tutorial activity design, tutorial unit program, student activity sheet, and collaborative ability test for the purpose of developing student collaboration skills. Based on the results of the validation, blended learning model developed is categorized valid, so it can be implement on learning process to promote physic students' critical thinking skill. A valid learning model can help teachers and lecturers to organize/design learning according to understood principles (Kimbell \& Stables, 2007; Seechaliao et al., 2012).

The blended learning model developed has certain characteristics and goals and fulfills aspects of validity, practicality, and effectiveness. Effective teaching is possible if the teaching process is designed according to the principles in teaching planning theory (Honebein \& Honebein, 2015) and the model developed is in accordance with that statement. The applicability of lesson plan was very good categorized (percentage: 86\%) (Figure 2). The score was attained because the lesson plan was well organized with the following accounts (1) different characters of students; (2) involving students' active participation; (3) promoting students' motivation to read; (4) providing feedback; (5) suitability and equality; (6) and 
utilization of IT (Widada, 2016). These characteristics are subject to possess by lecturers when it comes to designing a lesson plan. The differences of students' characters require different teaching techniques for promoting their participation. The students' participation in the class is highly determined by their characteristics (Sanjaya, 2012). This includes their learning styles such as visual, auditory, and kinesthetic (Brown, 2006). The choice of approach, strategies and learning model in the class plays crucial roles in the creation of engaging learning environment that may engage all the students in learning. The achievement of learning objectives should be represented clearly on procedural basis when designing the lesson plan. The following are the components of standardized lesson plans, namely (1) the provision of course identity; (2) course description; (3) learning objectives; (4) learning goals; (5) description of learning activities; (6) references; (7) and appendixes. The appendixes include learning materials and evaluation instruments (Ratumanan \& Laurens, 2006).

Apart from the challenges found in this study, the students' responses to learning using the blended learning model showed a positive response. Students enjoy learning $(90 \%)$, are motivated $(72 \%)$, and are helped by learning media $(94 \%)$ which are integrated in the blended learning model. The use of a relatively new learning model for students causes more motivation in learning and increases the achievement of learning objectives (Driyani, 2018; Astika et al., 2019; Latifa et al., 2020) where in this research is students' critical thinking skill. Previous research results showed positive impact on students' learning outcome and improve students' understanding of learning materials (Tubagus et al., 2019). Similar results also found that development of e-learning system improve students' cognitive skills (Khlaisang \& Likhitdamrongkiat, 2015) and has significant impact on students' learning outcome such as open-mindedness (Kintu \& Zhu, 2016).

Students feel more motivated in learning that is oriented towards the process of inquiry because of confrontation through the presentation of authentic phenomena that are relevant to the learning material (Asy'ari, Hidayat, et al., 2019; Muhali et al., 2019; Verawati et al., 2020);. In line with these results, (Banyen et al., 2016) found that the blended learning model can improve student learning outcomes, but it is not explained in detail the intended learning outcomes. The study which implements a project-based learning and blended learning model that is integrated with ethno-stem also states that students' critical thinking skills improve after learning in the components of simple explanation, basic skills, inference, and deep-explanation (Sumarni \& Kadarwati, 2020). On the other hand, it is explained that the blended learning problem based instruction model can improve students' critical thinking skills in the aspects of basic classification, in-depth classification, assessment, inference, and strategy in thermodynamics subjects (Marnita et al., 2020).

\section{Conclusions and Suggestions}

Based on the research finding, can be concluded that the blended learning model is valid in terms of content even it constructs in developing the students' critical thinking skills based on the experts' raters, effective in promoting the students' critical thinking skills, and can be applied and implemented easily and practically. The learning model developed meets a high quality learning model, which is grounded by learning theories, syntactic of learning model, specific purposes of learning model, and management system and learning environment. This model can be used as an alternative to improve critical thinking skills in teaching materials and other higher order thinking components.

\section{Acknowledgements}

If any, thank you notes addressed to official institutions or individuals as funders or have made other contributions in research shall be provided. Acknowledgments shall also be completed with the research contract letter number. 


\section{References}

Ally, M. (2004). Using learning theories to design instruction for mobile learning devices. Engineering Education.

Anas Pratama, H. F., \& Arief, S. (2019). Pengaruh Pemanfaatan E-Learning, Lingkungan Teman Sebaya, Dan Motivasi Belajar Terhadap Prestasi Belajar. J-PIPS (Jurnal Pendidikan IImu Pengetahuan Sosial). https://doi.org/10.18860/jpips.v6i1.7811.

Anggraeni, D. M., \& Sole, F. B. (2018). E-Learning Moodle, Media Pembelajaran Fisika Abad 21. Jurnal Penelitian Dan Pengkajian IImu Pendidikan: E-Saintika. https://doi.org/10.36312/e-saintika.v1i2.101.

Arends, R. I. (2012). Learning to Teach (9th Editio). McGraw-Hill.

Asy'ari, M., Hidayat, S., \& Muhali, M. (2019). Validitas dan efektivitas prototipe buku ajar fisika dasar reflektif-integratif berbasis problem solving untuk meningkatkan pengetahuan metakognisi. Jurnal Inovasi Pendidikan IPA. https://doi.org/10.21831/jipi.v5i2.27089.

Asy'ari, M., Ikhsan, M., \& Muhali. (2019). The effectiveness of inquiry learning model in improving prospective teachers' metacognition knowledge and metacognition awareness. International Journal of Instruction, 12(2), 455-470. https://doi.org/10.29333/iji.2019.12229a.

Bahtiar, Rahayu, Y. S., \& Wasis. (2018). Developing Learning Model P3E to Improve Students' Critical Thinking Skills of Islamic Senior High School. Journal of Physics: Conference Series. https://doi.org/10.1088/1742-6596/947/1/012067.

Baker, R. G. (1997). Colin Marsh (1996) Handbook for Beginning Teachers. Addison Wesley Longman: Australia. 406 pp. Australian Journal of Teacher Education. https://doi.org/10.14221/ajte.1997v22n2.8.

Banyen, W., Viriyavejakul, C., \& Ratanaolarn, T. (2016). A blended learning model for learning achievement enhancement of thai undergraduate students. International Journal of Emerging Technologies in Learning. https://doi.org/10.3991/ijet.v11i04.5325.

Baser, J. A., Saion, R., Manap, S. S. A., Hasan, A., \& Abdul Razzaq, A. R. (2016). Barriers of Inculcating Critical Thinking Skills in Teaching and Learning Process. Advanced Science Letters, 22(12), 4004-4006. https://doi.org/10.1166/asl.2016.8151.

Bensley, D. A., \& Murtagh, M. P. (2012). Guidelines for a Scientific Approach to Critical Thinking Assessment. Teaching of Psychology, 39(1), 5-16. https://doi.org/10.1177/0098628311430642.

Berge, Z. (2013). e-Moderating: The key to teaching and learning online. Distance Education, 34(3), 391-395. https://doi.org/10.1080/01587919.2013.835769.

Birch, D., \& Volkov, M. (2007). Assessment of online reflections: Engaging English second language (ESL) students. Australasian Journal of Educational Technology. https://doi.org/10.14742/ajet.1254.

Borich, G. D. (2016). Observation Skills for Effective Teaching. In Observation Skills for Effective Teaching. https://doi.org/10.4324/9781315633206.

Brown, H. D. (2006). Principles of language learning and Teaching (5th Edition). In Pearson Education ESL.

Chaeruman, U. A. (2018). Mendorong Penerapan E-Learning Di Sekolah. Jurnal Teknodik. https://doi.org/10.32550/teknodik.v12i1.417.

Davies, M., \& Barnett, R. (Eds.). (2015). The Palgrave handbook of critical thinking in higher education. Palgrave Macmillan.

Deperlioglu, O., \& Kose, U. (2013). The effectiveness and experiences of blended learning approaches to computer programming education. Computer Applications in Engineering Education, 21(2), 328-342. https://doi.org/10.1002/cae.20476.

Dewi, C. A. (2013). Pengaruh Blended Learning Dalam Pembelajaran Berbasis Masalah (Pbl) Terhadap Hasil Belajar Mahasiswa Ikip Mataram Pada Materi Pencemaran Lingkungan. Prisma Sains: Jurnal Pengkajian IImu Dan Pembelajaran Matematika Dan IPA IKIP Mataram. https://doi.org/10.33394/j-ps.v1i1.514. 
Dziuban, C., Graham, C. R., Moskal, P. D., Norberg, A., \& Sicilia, N. (2018). Blended learning: The new normal and emerging technologies. International Journal of Educational Technology in Higher Education, 15(1), 3. https://doi.org/10.1186/s41239-017-0087-5.

Effendi, H., \& Hendriyani, Y. (2020). The Conceptual and Hypothetical Model of Interactive Blended Problem Based Learning. JPI (Jurnal Pendidikan Indonesia). https://doi.org/10.23887/jpi-undiksha.v8i2.24162.

Ennis, R. H. (1993). Critical thinking assessment. Theory Into Practice. https://doi.org/10.1080/00405849309543594.

Fenton, C., \& Watkins, B. W. (2014). Meeting of the minds: Online matching program for teaching and learning styles? Community College Journal of Research and Practice. https://doi.org/10.1080/10668926.2012.748380.

Fisher, A. (2011). Critical Thinking An Introduction Second edition. In Cambridge University Press.

Fitriani, H., Asy'ari, M., Zubaidah, S., \& Mahanal, S. (2019). Exploring the prospective teachers' critical thinking and critical analysis skills. Jurnal Pendidikan IPA Indonesia. https://doi.org/10.15294/jpii.v8i3.19434.

Fraenkel, J. R., Wallen, N. E., \& Hyun, H. H. (2011). How to design and evaluate research in education. McGraw-Hill Companies, Inc.

Garrison, D. R., \& Vaughan, N. D. (2012). Blended Learning in Higher Education: Framework, Principles, and Guidelines. In Blended Learning in Higher Education: Framework, Principles, and Guidelines. https://doi.org/10.1002/9781118269558.

Gelder, T. van. (2005). Teaching Critical Thinking: Some Lessons From Cognitive Science. College Teaching. https://doi.org/10.3200/CTCH.53.1.41-48.

Graham, C. R. (2015). Emerging Practice and Research in Blended Learning. In Handbook of Distance Education. https://doi.org/10.4324/9780203803738.ch21.

Guo, L., \& Wang, J. (2021). Relationships between teacher autonomy, collaboration, and critical thinking focused instruction: A cross-national study. International Journal of Educational Research, 106, 101730. https://doi.org/10.1016/j.ijer.2020.101730.

Hake, R. R. (1999). Analyzing change/gain scores. Unpublished.[Online] URL: Http://Www. Physics. Indiana. Edu/ Sdi/AnalyzingChange-Gain. Pdf, 16(7), 1073-1080.

Harding, A., Kaczynski, D., \& Wood, L. (2012). Evaluation of blended learning: Analysis of qualitative data. Proceedings of The Australian Conference on Science and Mathematics Education (Formerly UniServe Science Conference).

Hermawnato, Kusairi, S., \& Wartono. (2013). Pengaruh Blended Learning Terhadap Penguasaan Konsep Dan Penalaran Fisika Peserta Didik Kelas X. Jurnal Pendidikan Fisika Indonesia. https://doi.org/10.15294/jpfi.v9i1.2582.

Honebein, P. C., \& Honebein, C. H. (2015). Effectiveness, efficiency, and appeal: Pick any two? The influence of learning domains and learning outcomes on designer judgments of useful instructional methods. Educational Technology Research and Development, 63(6), 937-955. https://doi.org/10.1007/s11423-015-9396-3.

Jones, R. H., Garralda, A., Li, D. C. S., \& Lock, G. (2006). Interactional dynamics in on-line and face-to-face peer-tutoring sessions for second language writers. Journal of Second Language Writing. https://doi.org/10.1016/j.jslw.2005.12.001.

Kasalei, A., Amini, M., Nabeiei, P., Bazrafkan, L., \& Mousavinezhad, H. (2020). Barriers of critical thinking in medical students' curriculum from the viewpoint of medical education experts: A qualitative study. Journal of Advances in Medical Education \& Professionalism, 8(2). https://doi.org/10.30476/jamp.2020.83053.1080.

Kaunang, S. T. G., \& Usagawa, T. (2017). A New Approach for Delivering e-Learning Complex Courses in Indonesia. International Journal of E-Education, e-Business, eManagement and e-Learning. https://doi.org/10.17706/ijeeee.2017.7.2.132-145.

Khlaisang, J., \& Likhitdamrongkiat, M. (2015). E-learning System in Blended Learning Environment to Enhance Cognitive Skills for Learners in Higher Education. Procedia Social and Behavioral Sciences, 174, 759-767. https://doi.org/10.1016/j.sbspro.2015.01.612. 
Kimbell, R., \& Stables, K. (2007). Researching Design Learning: Issues and Findings from Two Decades of Research and Development. Springer Netherlands. https://doi.org/10.1007/978-1-4020-5115-9.

Kintu, M. J., \& Zhu, C. (2016). Student Characteristics and Learning Outcomes in a Blended Learning Environment Intervention in a Ugandan University. Electronic Journal of ELearning, 14(3), 181-195.

Kintu, M. J., Zhu, C., \& Kagambe, E. (2017). Blended learning effectiveness: The relationship between student characteristics, design features and outcomes. International Journal of Educational Technology in Higher Education, 14(1), 7. https://doi.org/10.1186/s41239-017-0043-4.

Larsson, K. (2017). Understanding and teaching critical thinking-A new approach. International Journal of Educational Research, 84, 32-42. https://doi.org/10.1016/j.ijer.2017.05.004.

Lynch, M. (2020). \{E-Learning\} During A Global Pandemic. Asian Journal of Distance Education.

Marnita, Taufiq, M., Iskandar, \& Rahmi. (2020). The effect of blended learning problembased instruction model on students' critical thinking ability in thermodynamic course. Jurnal Pendidikan IPA Indonesia. https://doi.org/10.15294/jpii.v9i3.23144.

Moore, T. (2013). Critical thinking: Seven definitions in search of a concept. Studies in Higher Education, 38(4), 506-522. https://doi.org/10.1080/03075079.2011.586995.

Muhali, Yuanita, L., \& Ibrahim, M. (2019). The validity and effectiveness of the reflectivemetacognitive learning model in improving students' metacognitive ability in Indonesia. Malaysian Journal of Learning and Instruction.

Murgado-Armenteros, E. M., Torres-Ruiz, F. J., \& Vega-Zamora, M. (2012). Differences between Online and Face to Face Focus Groups, Viewed through Two Approaches. Journal of Theoretical and Applied Electronic Commerce Research, 7(2), 15-16. https://doi.org/10.4067/S0718-18762012000200008.

Nieveen, N. (1999). Prototyping to Reach Product Quality. In Design Approaches and Tools in Education and Training (pp. 125-135). Kluwer. https://doi.org/10.1007/978-94-0114255-7_10.

Phillips, D. C. (2007). Theories of teaching and learning. In A Companion to the Philosophy of Education. https://doi.org/10.1002/9780470996454.ch17.

Prayitno, W. (2015). Implementasi Blended Learning dalam Pembelajaran pada Pendidikan Dasar dan Menengah. Artikel LPMP D.I. Yogyakarta.

Prayogi, S., Yuanita, L., \& Wasis, L. (2018). Critical inquiry based learning: A model of learning to promote critical thinking among prospective teachers of physic. Journal of Turkish Science Education. https://doi.org/10.12973/tused.10220a.

Ramsay, G. (2001). Teaching and Learning with Information and Communication Technology: Succes Through a Whole School Approach. Building on the Future, 1-9.

Ratumanan, G. T., \& Laurens, T. (2006). Evaluasi hasil yang relevan dengan memecahkan problematika belajar dan mengajar. Alfabeta.

Riduwan. (2007). Skala Pengukuran Variabel-variabel Penelitian. In Alfabeta, Bandung.

Rombout, F., Schuitema, J. A., \& Volman, M. L. L. (2021). Teachers' implementation and evaluation of design principles for value-loaded critical thinking. International Journal of Educational Research, 106, 101731. https://doi.org/10.1016/j.ijer.2021.101731.

Sanders, M., Moulenbelt, J., \& Philosophy Documentation Center. (2011). Defining Critical Thinking: How Far Have We Come? Inquiry: Critical Thinking Across the Disciplines, 26(1), 38-46. https://doi.org/10.5840/inquiryctnews20112616.

Sanjaya, W. (2012). Perencanaan dan Desain Sistem Pembelajaran Edisi Pertama. In Prenada Media Group.

Saputra, R., Jalinus, N., \& Krismadinata. (2019). Development of Blended Learning Model Based on Project in Computer Network Design and Management. Journal of Physics: Conference Series, 1387, 012010. https://doi.org/10.1088/1742-6596/1387/1/012010.

Seechaliao, T., Natakuatoong, O., \& Wannasuphoprasit, W. (2012). The validation of an instructional design and development model based on engineering creative problem 
solving principles to develop reative thinking skills of undergraduate engineering students. IPEDR, 30. http://www.ipedr.com/vol30/19-ICEMI\%202012-M00032.pdf.

Setyowati, A., Subali, B., \& Mosik. (2011). Implementasi Pendekatan Konflik Kognitif Dalam Pembelajaran Fisika Untuk Menumbuhkan Kemampuan Berpikir Kritis Siswa Smp Kelas Viii. Jurnal Pendidikan Fisika Indonesia, 7(2), 89-96. https://doi.org/10.15294/jpfi.v7i2.1078.

Siron, Y., Wibowo, A., \& Narmaditya, B. S. (2020). Factors Affecting The Adoption Of ELearning In Indonesia: Lesson From Covid-19. Journal of Technology and Science Education. https://doi.org/10.3926/jotse.1025.

Staker, H., \& Horn, M. B. (2012). Classifying K-12 Blended Learning. Innosight Institute.

Suhirman, Prayogi, S., \& Asy'ari, M. (2021). Problem-Based Learning with CharacterEmphasis and Naturalist Intelligence: Examining Students Critical Thinking and Curiosity. International Journal of Instruction, 14(2), 217-232.

Suhirman, Yusuf, Muliadi, A., \& Prayogi, S. (2020). The effect of problem-based learning with character emphasis toward students' higher-order thinking skills and characters. International Journal of Emerging Technologies in Learning, 15(6), 183-191. https://doi.org/10.3991/IJET.V15I06.12061.

Sumarni, W., \& Kadarwati, S. (2020). Ethno-stem project-based learning: Its impact to critical and creative thinking skills. Jurnal Pendidikan IPA Indonesia. https://doi.org/10.15294/jpii.v9i1.21754.

Sunarto, M. J. D. (2021). The Development of Flipped Learning Model Based on MyBrilian to Support Planned Online Learning. Jurnal Penelitian Dan Pengkajian IImu Pendidikan: E-Saintika, 5(1), 27. https://doi.org/10.36312/e-saintika.v5i1.379.

Syarif, I. (2013). Pengaruh model blended learning terhadap motivasi dan prestasi belajar siswa SMK. Jurnal Pendidikan Vokasi. https://doi.org/10.21831/jpv.v2i2.1034.

Thiagarajan, S., Semmel, D. S., \& Semmel, M. I. (1974). Instructional development for Training teacher of exceptional. Indiana University.

Trilling, B., \& Fadel, C. (2009). What is 21st Century Learning? 21st Century Skills: Learning for Life in Our Times.

Tubagus, M., Muslim, S., \& . S. (2019). The Impact of The Development of Blended Learning Models Using Computer applications in Higher Education. International Journal of Educational Research Review, 4(4), 573-581. https://doi.org/10.24331/ijere.628410.

Verawati, N. N. S. P., Wahyudi, W., \& Ayub, S. (2020). Pengaruh Model Pembelajaran Inquiry-Creative-Process (ICP) terhadap Kemampuan Berpikir Kritis Mahasiswa Calon Guru. Jurnal Penelitian dan Pengkajian IImu Pendidikan: e-Saintika, 4(1), 715. https://doi.org/10.36312/e-saintika.v4i1.151.

Wichadee, S. (2017). A Development of the Blended Learning Model Using Edmodo for Maximizing Students' Oral Proficiency and Motivation. International Journal of Emerging Technologies in Learning (IJET), 12(02), 137. https://doi.org/10.3991/ijet.v12i02.6324.

Widada, W. (2016). Sintaks Model Pembelajaran Matematika Berdasarkan Perkembangan Kognitif Peserta Didik. Jurnal Pendidikan Matematika Raflesia.

Yongxing, W. (2008). Blended Learning Design for Software Engineering Course Design. 2008 International Conference on Computer Science and Software Engineering, 345348. https://doi.org/10.1109/CSSE.2008.198.

Yuliati, D. I., Yulianti, D., \& Khanafiyah, S. (2012). Pembelajaran Fisika Berbasis Hands on Activities Untuk Menumbuhkan Kemampuan Berpikir Kritis Dan Meningkatkan Hasil Belajar Siswa Smp. Jurnal Pendidikan Fisika Indonesia, 7(1), 23-27. https://doi.org/10.15294/jpfi.v7i1.1064.

Yustina, Syafii, W., \& Vebrianto, R. (2020). The effects of blended learning and project-based learning on pre-service biology teachers' creative thinking skills through online learning in the COVID-19 pandemic. Jurnal Pendidikan IPA Indonesia. https://doi.org/10.15294/jpii.v9i3.24706. 